\title{
The Low Value of Equality and Social Inclusion in Fragmented and Discriminatory Latin American Societies - Pensions and Health
}

\author{
Cristina Gomes \\ S Facultad Latinoamericana de Ciencias Sociales, \\ FLACSO-Mexico, Mexico
}

\begin{abstract}
This article aims to analyze the fragmented mix of social policies in Latin America, guided by minimalist principles and instruments of liberal thinking on individual meritocracy and contributory insurance, in order to discuss the challenges to and possibilities of developing universal policies. The article describes the historically social, economic and political contexts and pressures that frame the process of building fragmented social policies in the region; the contradictions, disadvantages, and limited achievements of these fragmented systems in terms of coverage, generosity and quality of health and pensions. Results show that expansive and fragmented welfare policies reproduce differences in quality and scope and increase social inequalities and conflicts; the challenges of building universal rights, citizenship and equality in Latin America, considering current public-private agreements, political coalitions, and interclass alliances, and the need to reorient social policies in order to overcome conflicts of interest, discrimination and market resistance, and to promote equality.
\end{abstract}

Keywords: values; equality; social inclusion; health; pensions; social policies.

\section{INTRODUCTION}

This article analyses why universalism is not a reality in Latin America, from a relational and historic framework of poverty and inequalities, and how each society legitimized the historical process from which Bismarckian's social security systems have emerged, expanded and been legitimated along with the current social security and rights in the region. This process is analyzed from a framework of unequal social citizenship and economic, social, political, and institutional weakness reproduced since the colonization to the 1980s, after which neoliberal measures of the Washington Consensus were implemented under the influence of international organizations (such as the WB, MIF, IADB), weakening further the role of the State and citizenship rights, through privatizations in social welfare schemes.

States are expected to provide universal welfare, and universalism is socially and historically constructed through complex processes of negotiation, conflict, and agreement in a society. Although universalism seems a hegemonic tendency, its foundations and principles have been constantly tested and questioned, and followed different historical ways and paths, from complete to "partial" universalism, according to what is considered as "possible universalism" in relation to universal rights, agreed welfare, and the equal distribution of resources. The dynamics of social inequalities establish criteria of inclusion and exclusion based on class, gender, race-ethnicity, disability, age and other dimensions, extending to unequal citizenship status and the exercise of rights. The historical processes of unequal expansion in social rights and citizenship legitimized different universalisms, based on different levels, scope and qualities of social citizenship and welfare entitlements, depending on how each society builds, recognizes and legitimizes them as universal or not. Universal human rights and welfare States 
have become progressively recognized and legitimized and have expanded their influence until becoming hegemonic through political, moral and intellectual processes of consensus and conflicts, antagonisms and articulation in specific societies, times and geographic spaces. As a result, different ways to configure and to legitimize universalism co-exist over time, being similar, different or even antagonistic entities [1].

There are two predominant conceptual frameworks to understand and legitimize universalism since the interception of Welfare. Liberal theory or the doctrine of the "equal worth of each individual as an inherent part of the human condition and bestowed on individual human beings from birth and that supposedly ensures equal opportunity through the redistribution of opportunities rather than outcomes"; in contrast to the "social democratic tradition and result of political struggles of marginalized groups who demand rights and citizenship" [2].

In Latin America, liberalism has historically predominated as an economic and social orientation. The idea of minimal State and the corresponding minimal citizenship and rights limited to privileged and elitist groups -have reproduced historic high levels of poverty, inequality, and discrimination of the majority of the population. Social policies were transferred to America when Bismarckian social security was the predominant model in Europe, which has been the exclusive model adopted in Latin America up to the last decades of the 20th Century, and followed by other focused and fragmented social policies based on restrictive criteria of inclusion and exclusion.

Latin America is the region with the highest levels of socioeconomic inequality and also the greatest ethnic-racial diversity in the world. In 2010, the indigenous population represented 42 million people or $7.8 \%$ of the total, and $80 \%$ of them live in Mexico, Peru and Guatemala. Poverty affects $43 \%$ of the indigenous, and extreme poverty affects $24 \%$ - more than double the percentage - compared to non-indigenous Latin Americans. The indigenous are likely to live in rural areas, in poor households, and to work in the informal sector with low access or right to social security, infrastructure, health services, and hygiene technology, including contraceptive methods [3]. Structural inequalities and persistent poverty result in poor, female, indigenous and afro-descendant people with lower education levels and living in slums and rural areas, dying earlier, having a greater number of children than their counterparts.

Afro-descendants total 133 million people and represent $24 \%$ of the population in the region; 49.6\% live in Brazil (105 million), $11.93 \%$ in Panama, 9.45\% in Colombia, 8.51\% in Ecuador, 8.13\% in Costa Rica, and are also present in Cuba, Venezuela and Mexico [4-5]. Like the indigenous, this group is also over-represented among the poor and under-represented in policies and services, excluded by stereotypes and ethnic-social barriers. Half of their households are poor and they have a higher probability of being poor - poverty is over twice as high for Afro-descendants in Brazil, three times higher in Uruguay, and over 10\% points higher in Colombia, Ecuador, and Peru. They are twice as likely to live in poor urban neighborhoods, in Brazil, Colombia, Costa Rica, Ecuador, Mexico, and Uruguay, when compared to white groups [6-7].

\section{Literature Review and Document Analysis}

\section{METHOD}

The purpose of the literature review in this is article is to examine and to relate two fields of research developed in Latin America: a. the historical process in which citizenship and rights were constructed in fragmented societies that exclude and discriminate population groups, the market pressures, obstacles and efforts towards social inclusion made by governments and 
international organizations; $b$. the comparative analysis of quantitative data and policy information available in the field of coverage and reforms in health and pensions systems [8].

The literature review combined these concepts, data and measures based on document analysis of programs proposals, operation rules, summaries, organizational and evaluation reports on programs and institutional reforms and database of various public records of international organizations and governments. Therefore, in this article, the literature review is not one step of the research study, but it represents the embedded study.

The search of a set of articles that include different topics of interest and research methods in literature review represents itself a formal data collection process to gather several perspectives and methods in a comprehensive way following an analytical logic for identifying, recording, understanding and discuss the information related to the three topics of interest. The information was organized in order to organize, combine and integrate the set of information in a mixed research study [9].

The combination of the fields of the historical construction of fragmented citizenship, welfare and rights are the bases of the hypothesis that there is a low value of equality in Latin American societies, that support a change in the analysis of the quantitative and qualitative information in within the same literature review. This combination allows to summarize and logically organize the literature review in order to address the related hypotheses from different fields of research, with the objective of integrate the researches analysis and results.

\section{BACKGROUND, THE CONTEXT OF THE EMERGENCE OF FRAGMENTED CITIZENSHIP AND SOCIAL RIGHTS IN LATIN AMERICA}

Social citizenship and welfare are constructs related to the history of each country and to economic, social, political and population contexts. In Europe, from 1883 to 1941, the Bismarck systems of social insurance were created before industrialization and consolidated in the following decades $[1,10]$. This contributory model of social insurance was transferred to Latin America at the end of the 19th Century.

For four centuries, Latin America has had an history of economic, social, political and cultural values centrally based on colonial and dependent roots - indigenous genocide and slavery, farms, extensive plantations, mining enclaves, and the associated social patterns of exportminded commodities and related exchange mechanisms [11], fights for independency, and a work force dependent almost exclusively on the bondage of original indigenous and African slaves and their mixed descendants, with a very small paid work force. These groups represent the majority or a significant portion of the populations, who, for five centuries, have had their identity denied or limited, as well as their citizenship recognition and participation in development, formal labor market, land distribution, social welfare and rights.

Unlike Asia and Africa, Latin America joined the European mercantilist expansion early and deeply for three centuries and, after many years of war most of its countries achieved their political independence at the end of the 19th century, adopting oligarchic-military political systems and economic liberalism to export primary products - agricultural, livestock, forestry and minerals. The export of these products has predominated in Latin American GDP's composition until 1930. The most relevant issues in Latin American literature are the persistence of economic underdevelopment, dependence, liberal-oligarchic late republics with authoritarian and elitist regimes based on personalism, nepotism, patrimonialism and racism, associated with extreme poverty, inequalities and the exclusion of most of the population from welfare, citizenship and political decisions [12-15]. 
Social citizenship has been belated, incomplete and fragmented in Latin America. In the beginning of the 1900 s, corporate insurance was created to attend to problems linked to modern conditions of urban work, when liberalism considered poverty and class inequalities to be necessary factors for development ("the need for maintaining a large poor class... so that they would have the incentive to work") [16]. Social protection was provided on the moral basis of charity and philanthropy, and the State only intervened in cases of serious threats such as epidemics or disasters.

At the beginning of the 20th century, Latin America was moving slowly from agricultural export to industrialization, based mainly on trade exchange and with high flows of Europeans immigrants [17]. In the 1930s, the region slowly started to move from an agricultural colony regimen to the world capitalist system, mostly subordinated to Spain/Portugal, France, the United Kingdom and, later, to the United States. Under pressure from Britain, the oligarchic elites were progressively forced to adopt free labor and used the abundance of land and capital, and labor scarcity to attract European, Asian and Syrian-Lebanese immigrants. Between 1820 and 1930, 13 million Europeans moved to Argentina, Brazil, Chile and Uruguay. They were selected due to their high literacy levels, previous experience in manufacturing, special skills and entrepreneurial capacities, and created and demanded schools and welfare, pressing for public funding [20].

Massive European immigration imported the pressures of workers movements for rights and citizenship, including the prevalent Bismarck model of social security based on obligatory cofinancing by employers and formal workers. The most developed sectors, such as railroads, banks, commerce, ports, military and public servants created corporative mutual funds to finance healthcare and income protection against sickness, accidents, disability, agingretirement. Mutual funds were managed by the laborers and companies in order to guarantee workers loyalty and productivity. The pioneer countries in Latin America were Uruguay, Chile, Brazil, Argentina and Cuba (1883-1941) [19-21].

Most of the populations were indigenous, black and their mixed descendants, who were mostly illiterate and unqualified in the new economic sectors, continuing to work in the precarious and informal labor market and without insurance. Cuba created the first Ministry of Health in 1902, followed by other countries just in the 1930s (Chile, Peru, Venezuela and Paraguay) and successively until Ecuador in 1967, importing sanitation infrastructure and health technologies - immunization and then antibiotics $[17,21]$.

\section{The unification of the mutual organizations in National Institutes of Social Security.}

During the period 1930-1950, the Latin America economy followed the Keynesian perspective from Europe: the State assumed an active economic role to promote economic growth, and promoted citizenship and social welfare policies.

The International Labor Organization established social security as a universal right and, in Latin America, nationalist States assumed this responsibility. As the majority of the population continued to work in the informal labor market, the States maintained public health systems financed by taxes to poor groups and unified the mutual organizations of formal workers in National Institutes of Social Security, for which the State became the third contributor and exclusive manager, extending the coverage to less organized formal workers, and controlled the common funds of National Institutes from the 1940s to the 1980s, facing strong resistance $[21,22]$. State bureaucracy alleged budget restrictions to cover large population groups, while the worker unions were concerned about decreases in the quality of benefits, affected by the 
lower salaries of the new contributors. The most powerful groups - the military, the police, and public servants - kept their corporative systems separated.

Nevertheless, the unification and expansion multiplied the coverage of social security impressively. In Brazil, the number of affiliated increased 20 times in 15 years, and, in 1945, the institute had 2.8 million affiliates [17]. This budget accumulation allowed governments to invest in economic development, generating more formal employment and new contributors. However, informal workers continued to represent around $40 \%$ of the population and social citizenship continued being subordinated to labor market contributions. [19,20].

In 1942, the United Kingdom and most European countries adopted the universal Beveridge model of social citizenship, financed by fiscal resources. However, this model has never been adopted in Latin America.

\section{The crisis of the National Institutes of Social Security and the separation of the budgets and management of health and pensions.}

During the period 1950 to 1960, the economy and work force were reallocated from agriculture to industry and commerce, increasing formal work and social inclusion, particularly in Brazil, Mexico, and Peru. In the 1970s civil-military dictatorships predominated in Latin American, associated with foreign capital, which, in the following decades, promoted reforms to privatize social security, transferring the large budget of national institutes to the private finance sector. The first experience occurred in Chile under Pinochet's regime, advised directly by Milton Friedman [22].

In the 1970's, healthcare experienced increasing costs around the world, due to the development of the market technology and inflationary prices, and a growing demand, which generated a reallocation of State financing to health sector. Pensions funds were depleted, while being used to cover the growing health spending.

The 1980s are considered the "lost decade" of Latin America, with economic crisis, hyperinflation, increases in unemployment, informality, poverty and inequalities, aggravated by the privatization of public enterprises, and the use of funds from social security institutes to compensate economy imbalances [23]. All this affected mainly small businesses, increasing informality and unemployment. Finally, still 130 million poor people continued without social security, and most of the workers weren't contributing to the institutes [24].

New reforms separated health funds and pensions savings. In the 1980s huge popular urban movements defeated dictatorships, and democratic neoliberal governments were elected.

\section{The privatization of social security.}

As the hegemonic idea of solidarity with the previous collective public funds of formal workers didn't guarantee a real solidarity among all the actors, generations and sectors involved, the private sector emerged as the exclusive defender of the individual interest of the formal workers - the small middle class with saving potential.

After 1989, the international financial agencies and the governments promoted constitutional reforms to transfer the collective pensions funds managed by the State to individual private accounts, and defined benefits were substituted by defined contributions. Structural reforms privatized pensions and different levels of health care in Argentina, Bolivia, Chile, Colombia, Costa Rica, El Salvador, Mexico and Peru, and "no countries in the region has remained indifferent to the prospect of inevitable reform" [25]. 
Formal workers were convinced by promises of individual advantages and privileges through high future returns. Their savings were individualized and transferred to an increasingly deregulated and unstable private finance, affected by market bankruptcies, management decentralization, and competition among suppliers - part of contributions were used to pay high administrative taxes and propaganda, making future benefits more unfeasible. Social rights and citizenship became more fragmented and inefficient [26].

The subsequent crises led the poor and the middle classes to lose their formal jobs and, also, part of their savings for future pensions. In 2002, unemployment was at $11 \%$ of the population and massive poverty affected 221 million people (increasing from $40 \%$ of the population in 1980 to $48 \%$ in 1990 and $44 \%$ in 2002) and social inequality increased from 0.484 during the $1970 \mathrm{~s}$, to 0.508 in the $80 \mathrm{~s}$, and to 0.522 in the $90 \mathrm{~s}$ [27].

The State no longer has the contributory public funding to increase safety nets and social protection, which previously amortized the impact of the crises and helped the economy to avoid recession. Moreover, several ex-contributors moved to poverty, and the minimal State developed the first focused strategies, with a minimal coverage, solely to mitigate extreme poverty [28].

After three decades, privatization of social security led to negative results: decreases in coverage, the level of pensions, regulation and supervision, and in social dialogue. There were also increases in administrative costs and in the public-private transition costs, along with the transference of the demographic risks to individuals [29].

\section{The emergence of non-contributory programs against poverty.}

The recurrent crisis of the 1990s led to the election of progressive parties, which governments combined diverse social policies: the expansion of social investment in economy (mainly in formal employment and contributions for social security), in education and health, increases in minimum wages and in the coverage, generosity and quality of non-contributory social policies focused on poor households [28-29,23]; the expansion of fellowships for university scholarships, vocational technical training, and people with disabilities, along with workshops on self-care, nutrition, the prevention and treatment of malnutrition, care of the elderly, and health insurance, as well as the inclusion in the formal labor market. Pensions were renationalized in Venezuela (2000), Ecuador (2002), Nicaragua (2005), Argentina (2008), and Bolivia (2009) [29].

Non-contributory social security coverage was extended. The Conditional Cash Transfers (CCTs), created from the 1990s in Brazil and Mexico to guarantee income, assistance to school and health services to poor, were expanded to 18 Latin American countries. CCTs average cost is around $0.56 \%$ of GDP [23]. In Brazil, the Previdencia Rural was approved in the 1988 Constitution, and covers $40 \%$ of rural workers, compared to $13 \%$ before the reform; in Argentina, the Moratorium system increased its coverage between $27 \%$ and $16 \%$ points for women and men, respectively, and the subsidy for minors under 18 years of age covered 29\% of all eligible children at a cost of $0.64 \%$ of GDP; In Chile, the non-contributory pension covers $60 \%$ of the poorest older adults. In the health sector, in 2010, the Popular Insurance of Mexico covered 43 million people and reduced the catastrophic expenses of families with health by $23 \%$, and the $70+$ pension program reduced the poverty gap from $0.61 \%$ to $0.46 \%$. In Colombia, the Subsidized Regime increased health coverage from $30 \%$ to more than $90 \%$ of the population[23]. 
The Previdencia Rural of Brazil costs around 0.89\% of the GDP. In Argentina, the Moratorium costs between $1.5 \%$ and $2 \%$ of GDP $[20,23,30]$, much below to the percentage of the CCTs in the region (Table 1).

Table 1. CCTs in Latin America

\begin{tabular}{|c|c|c|c|c|c|c|c|c|}
\hline & Program & $\begin{array}{c}\text { PIB } \\
\text { US\$ million }\end{array}$ & $\begin{array}{c}\text { PIB } \\
\text { per capita } \\
\text { US\$ } \\
\end{array}$ & $\begin{array}{l}\text { Expenses } \\
\% \text { of PIB }\end{array}$ & $\begin{array}{c}\text { Population } \\
\text { million }\end{array}$ & $\begin{array}{c}\text { Beneficiaries } \\
\text { thousand }\end{array}$ & $\begin{array}{c}\text { Population } \\
\text { Coverage \% }\end{array}$ & $\begin{array}{c}\text { Population } \\
\text { under nourished } \\
\%\end{array}$ \\
\hline Mexico & Prospera & $1,259,201$ & 10,293 & $0.41 \%$ & 124 & 27,000 & $21.4 \%$ & Below 5\% \\
\hline Brazil & Bolsa Familia & $2,243,804$ & 11,199 & $0.47 \%$ & 202 & 50,353 & $24.9 \%$ & Below 5\% \\
\hline Paraguay & Tekopora & 29,009 & 4,294 & $0.23 \%$ & 6.9 & 565 & $8.2 \%$ & $11 \%$ \\
\hline Bolivia & Bono Juanito Pinto & 30,601 & 2,868 & $0.64 \%$ & 10.8 & 1,825 & $16.9 \%$ & $19.5 \%$ \\
\hline Uruguay & PANES & 55,708 & 16,351 & $0.45 \%$ & 3.4 & 389 & $11.5 \%$ & Below 5\% \\
\hline Argentina & AUY & 611,726 & 14,760 & $0.54 \%$ & 41.8 & 3,328 & $8.0 \%$ & Below 5\% \\
\hline Total & & & & & 388,9 & 83,460 & $21.0 \%$ & \\
\hline
\end{tabular}

16 of the 17 countries consistently decreased poverty and inequality, and these results were not limited to CCTs, but are mainly due to the combination of policies mentioned above.

The Gini Coefficient fell in most of the countries, reducing by 6\% in Argentina, Brazil, Peru and Venezuela, and more than 3\% in Chile and Mexico, and 2\% in Colombia. Between 1990 and 2010 , infant mortality showed a reduction of 120 to 60 deaths per thousand births, maternal mortality decreased from 50 to 25 per 100 thousand births, and chronic malnutrition in children below five years of age fell from $25 \%$ to $12 \%$ of the population. Attendance at school improved, and the average number of years of schooling increased, and the health and educational conditions of girls reached equity or even exceeded those of boys [23].

As governments depended on pacts between all the sectors, even the elites predominant in the previous period, universalism was not a viable pattern of agreements. Even the expansion of focused non-contributory programs had been a theme that reproduces conflicts, intolerance and hatred of the elites and upper middle class against the most vulnerable groups, propagated by the monopolistic media in Latin America. Nonetheless, during the 2000s, for the first time, Latin America was able to reduce poverty and social inequalities, and expand further social protection coverage [23,31].

\section{Healthcare in Latin America}

Most countries in Latin America consider health as a universal derogation in their National Constitution: Bolivia, Brazil, Ecuador, Paraguay, Suriname, Venezuela and Cuba; others consider this derogation but do not refer to universalism; or just express the concern in guaranteeing access to health services (Costa Rica, Mexico). Recent reforms in Venezuela (1999), Bolivia (2009) and Ecuador (2008) incorporated health as a universal value. Some constitutions don't mention health as a derogation of the State, whereas others adhere to international instruments, states universal coverage or limit it to formal workers, or don't express this State responsibility on health. Ecuador, Paraguay, Bolivia and Venezuela include interculturalism as a principle for the organization of the health system (Table 2). 
Table 2. Health Systems in Latin America

\begin{tabular}{|c|c|c|c|c|c|c|}
\hline \multicolumn{2}{|c|}{$\begin{array}{l}\text { Model/ } \\
\text { Source of Financing }\end{array}$} & Subsidy/ Taxes & \multicolumn{2}{|c|}{$\begin{array}{l}\text { Bismarck Social Security/ } \\
\text { Contributory }\end{array}$} & & $\begin{array}{l}\text { Other/ } \\
\text { Private }\end{array}$ \\
\hline \multicolumn{2}{|c|}{ Conditions of membership } & $\begin{array}{l}\text { Focused on } \\
\text { poor }\end{array}$ & $\begin{array}{l}\text { Formal workers in } \\
\text { Private companies }\end{array}$ & & $\begin{array}{l}\text { Formal } \\
\text { workers in } \\
\text { Public } \\
\text { companies }\end{array}$ & $\begin{array}{l}\text { High \& } \\
\text { Middle class }\end{array}$ \\
\hline Manageme & & Public & Public & Private & Corporations & Private \\
\hline Country & $\begin{array}{l}\text { Universalism } \\
\text { Obligation State } \\
\text { Legal Framework }\end{array}$ & $\begin{array}{l}\text { Ministry of } \\
\text { Health } \\
\text { Coverage \% }\end{array}$ & $\begin{array}{l}\text { Institutes/ } \\
\text { National/State/ } \\
\text { Municipality }\end{array}$ & $\begin{array}{l}\text { Finance } \\
\text { sector }\end{array}$ & $\begin{array}{l}\text { Companies/ } \\
\text { Institution/ } \\
\text { Prepaid }\end{array}$ & $\begin{array}{l}\text { Private } \\
\text { Plans } \\
\text { Pre-paid }\end{array}$ \\
\hline Argentina & HRD* & $35.0 \%$ & $55.0 \%$ & - & Oil, military, & $8 \%$ \\
\hline Bolivia & Constitution & $\begin{array}{l}57.5 \% \\
\text { (co-payment) }\end{array}$ & $30.6 \%$ & - & & - \\
\hline Brazil* & Constitution & $\begin{array}{l}\text { Universal/ } \\
\text { Beveridge }\end{array}$ & States/Municipal & - & $\begin{array}{l}\text { Oil, military, } \\
\text { banks }\end{array}$ & $25 \%$ \\
\hline Chile & State implementer & - & $74 \%$ & $\begin{array}{l}17 \% \\
\text { ISAPRES }\end{array}$ & $2 \%$ military & $7 \%$ \\
\hline Colombia & Constitution & $48.4 \%$ & $\begin{array}{l}42.6 \% \text { POS (SS and } \\
\text { subsidy) }\end{array}$ & - & $\begin{array}{l}4.8 \% \text { oil, } \\
\text { military } \\
\text { teachers }\end{array}$ & $3 \%$ \\
\hline Costa Rica & $\begin{array}{l}\text { Constitution/only } \\
\text { formal workers }\end{array}$ & - & 87.6 & - & - & $2 \%$ \\
\hline Ecuador & Constitution & $70 \%$ & $\begin{array}{l}17 \% \text { urban+ } \\
6.5 \% \text { rural }\end{array}$ & - & $\begin{array}{l}1.6 \% \text { military } \\
1.8 \% \text { police }\end{array}$ & $8.2 \%$ \\
\hline Guyana & Constitution & $\begin{array}{l}\text { Universal/ } \\
\text { Beveridge }\end{array}$ & - & - & - & $7 \%$ \\
\hline México** & $\begin{array}{l}\text { Constitution } \\
\text { (protection) } \\
\text { Health Law: } \\
\text { universal coverage }\end{array}$ & $\begin{array}{l}\text { PS** } \\
\text { (co-payment) }\end{array}$ & $40 \%$ ? IMSS & - & $\begin{array}{l}\text { ISSSTE } 10 \% \text {, } \\
\text { oil, military, } \\
\text { etc. }\end{array}$ & - \\
\hline Paraguay & Constitution & $76 \% *$ & $16.4 \%$ & - & $\begin{array}{l}7 \% \\
\text { military/othe } \\
\mathrm{r}\end{array}$ & ONGs \\
\hline Peru & $\begin{array}{l}\text { Constitution/all } \\
\text { rights (no universal) }\end{array}$ & $39.3 \%$ (paid) & $20.7 \%$ & - & $4.7 \%$ & $\begin{array}{l}4.7 \% \text { and } \\
\text { ONGs }\end{array}$ \\
\hline Suriname & Constitution (all) & $24 \%$ (co-paid) & $\begin{array}{l}21 \% \text { SS MS+ONG } \\
\text { subs+Priv }\end{array}$ & & $\begin{array}{l}10 \% \\
\text { companies } \\
6 \% \text { mission } \\
\end{array}$ & $3 \%$ \\
\hline Uruguay & Constitution & $30 \%$ & $\begin{array}{l}53 \% \text { SS } \\
+ \text { ONG+Priv }\end{array}$ & & $\begin{array}{l}7 \% \text { military } \\
\text { and police }\end{array}$ & $\begin{array}{l}1.3 \% \text { and } \\
\text { ONGs }\end{array}$ \\
\hline Venezuela & Constitution & $\begin{array}{l}\text { Universal/ } \\
\text { Beveridge }\end{array}$ & $\begin{array}{l}17.5 \% \\
30 \% \\
\end{array}$ & & - & $11.7 \%$ \\
\hline
\end{tabular}

*The SUS - Sistema Unico de Saude (Unified Health System), was created by the constitution approved in 1988, which unified the services from the Health Ministry, subsided by the State for the poor and the services of the Social Security System - contributory base. The SUS attends free and equally all citizens, with no conditions to access to all the services.

**Incorporation of Human Rights Declaration

\section{Source: Temporao, 2012 and official data from México and Costa Rica.}

\section{Reforms in health systems.}

In Chile, health services were privatized in the 1970s and, in the 1980s-1990s, new health reforms reduced public spending and established focusing conditions - cost recovery or copayment. Formal workers could choose between private insurance (Isapres) and public insurance (Fonasa) but they only could contribute to one of these, interrupting the redistribution between workers with higher and lower incomes. Privatization implied a risk selection: the high-income and low-risk taxpayers sere concentrated in the private insurance, and the elderly, chronically ill, women and low-income groups in the underfunded public insurance (Fonasa). In the 2000's, progressive governments strengthened the public sector, which reached $75 \%$ of the population in 2011 [17,32]. Colombia reformed its health system in 1993, combining public financing, management, and regulation with private participation and 
three affiliation arrangements: a contributory scheme that included autonomy, a subsidized scheme for the poor and a regime of affiliates in the public sector. Coverage increased to $57 \%$ of the population in 2002, but financial transfers generated crises in hospitals [33].

In Costa Rica, health insurance included affiliated domestic and rural workers, peasants, the self-employed, micro and macro entrepreneurs, unpaid workers and pensioners. In Uruguay, health insurance did not cover the latter groups. Farmers, unpaid workers, and employees of large companies were excluded from health insurance in Peru. In the Dominican Republic, the public sector covered micro entrepreneurs [23].

In Brazil the corporate institutes were unified in 1966 and, in 1977, the State was converted into a buyer of private services, which favored corruption, particularly in hospitals. In 1988, the constitution approved a unified system to provide universal access and the decentralization - municipalities became the main providers of services and Health Councils were created in 1990 to promote the population's participation.

[32] identifies common trends in the reforms of Chile, Brazil and Colombia; fragmentation, public-private partnership, increasing inflationary costs, and decentralization to municipalities, all of which are factors of instability and crisis in financing, managing and evaluating these systems.

After these different reforms, health insurance coverage varies enormously: from $20 \%$ and $55 \%$ in Argentina to more than $70 \%$ of the population in Uruguay and Chile; and public insurance for mothers and children cover from $12 \%$ to $39 \%$ of the population in different countries.

In Colombia, Uruguay and Chile the financing is public (from compulsory contributions of formal workers) but the insurer can be public or private, with or without profit. In Chile, the mandatory contributions in private Isapres are individual plans and the price depends on the individual risk.

Ministries of Health and subnational governments deliver universal free healthcare for all citizens in five countries, covering from $35 \%$ to $76 \%$ of the population, as in Brazil and Venezuela, which unified services from contributory institutes with those from Ministries of Health in a universal system. Meanwhile, two other countries covered the uninsured population with targeted public insurance - Mexico and Chile.

Private insurance coverage is low in most countries, between $5 \%$ and $25 \%$ of the population and is through prepaid medicine companies, by individuals or companies.

The share of total health expenditures in GDP in our countries is very diverse, varying from 4\% to $9 \%$. And among private health expenditures, the participation of direct pocket payments in the act of use is high, mainly for the purchase of medicines. Medicines correspond to $50 \%$ to $97 \%$ of private expenses in the twelve countries [34]. This shows an important equity gap, as these expenses are highly regressive.

Reforms implemented in the 1990s maintained fragmentation and the perspective of private insurance, and individualization of risks, the breaking of solidarity and the fragmentation of the provision of services [35]. In the universalistic vision, financing is not a function of the health system, but a fundamental prerequisite for its operation, and must be guaranteed by the State. 


\section{Quality and inequalities in Health.}

Universal Health Coverage (UHC) includes equitable access to high-quality health services and financial protection for all, and depends on protection against financial risk or out of pocket family expenditures as well as health service inputs to infrastructure and human resources such as hospital beds, doctors, effective coverage measured through need, use and quality, access, effective treatments, health impact ,and the equitable distribution of health gains and improvements to reduce health disparities and protect women, the indigenous, Afrodescendants, rural residents, immigrants, etc.

Latin America is extremely unequal and is shifting towards complex health conditions, coexisting communicable and non-communicable diseases (NCDs), and external accidents and violence. In Argentina, when comparing the poorest and richest provinces, infant mortality is twice as high in the former, maternal mortality is eight-times higher, treatment in acute myocardial infarction-a strong predictor of mortality- is eight-times higher, cervical and colorectal cancer mortality are higher- and all are associated with poverty. In Brazil, Colombia, Costa Rica, Ecuador, Mexico, and Uruguay Afro-descendants are likely to live in areas with poor access to services and jobs, with higher levels of crime, violence, and a propensity to natural disasters, presenting higher mortality, morbidity (hypertension and diabetes), lower pre-natal care and anesthetic procedures when compared to white groups $[7,36]$. These differences are explained by regional variations in screening and lead-time between diagnosis and treatment, health coverage for cardiovascular risk factors, and screening practices for cancer prevention.

The realization of true universality in its entirety is analyzed through performance indicators in health. These can be classified as a) inputs-resources, professionals, facilities, supplies, service delivery, access, coordination, organization, and management of care, b) results success in providing adequate care, and c) impact - services provided are efficient and equitable, along with user experience (assessing patient-reported outcomes and people's confidence on the health system). In this article some indicators are selected to analyze a continuum of care from population-wide preventive measures to individualized care. [5, 37].

Latin American countries have adopted a strategy centered on primary care in order to advance the integration of health-care coverage while enhancing quality of care.

Adequate infrastructure includes facility density (hospital-beds per 100,000 population), doctor availability density (per 10,000 population), vaccine supply according to risk groups, service delivery of immunization such as Diphtheria-tetanus-pertussis vaccine dropout rate and Tuberculosis treatment success rate, the rate of patients with diabetes with at least one prescription of statins, and childhood vaccination for measles. Impact should also be included - life expectancy, for example.

High-quality care involves thorough assessment, detection of asymptomatic and co-existing conditions, accurate diagnosis, appropriate and timely treatment, referral when needed for hospital care and surgery, and the ability to follow the patients' progress and adjust the treatment course as needed.

Central American countries, Venezuela, Bolivia and Paraguay have levels on a parity with Africa - under 10 hospital beds per 10,000 inhabitants, followed by Colombia, Ecuador, the Dominican Republic, Peru and Mexico, with around 15 -16 hospital beds per 10,000 people. Chile, Brazil, Panama, and Uruguay have around 21-28 beds and only Argentina and Cuba come close to Europe's figures (50). 
Human resources are usually expressed as the number of qualified healthcare personal per 10,000 inhabitants. The WHO considers having fewer than 23 healthcare professionals (including doctors, nurses and midwives) for every 10,000 inhabitants insufficient to provide adequate care.

On average, there are 13 doctors for every 10,000 inhabitants worldwide and, in 2012, Latin American had in average 2.07 - similar to African figures - and only three countries recorded numbers higher than Africa (Mexico (2.2), Argentina (3.9) and Cuba (7.5)).

Immunization achieved high coverage: Measles first dose is higher than $90 \%$ in almost all countries except Dominican Republic and Paraguay. DPT3 coverage is over 90\%, except in Guatemala, Ecuador, Venezuela, Panama, and Bolivia. Polio immunization varies from $45 \%$ in Haiti, $72 \%$ in Brazil, $79 \%$ in Ecuador, $82 \%$ in Guatemala to more than $90 \%$ in the other countries.

Performance in quality and healthcare results, such as the success in treating tuberculosis in new cases cured has the lowest rate in Jamaica (23\%), with Argentina having (44\%), Paraguay (57\%), Chile (61\%), and Brazil (62\%). The percentage of cases of tuberculosis treated in health services varies from 18\% in Jamaica, is between $44 \%$ and $54 \%$ in Argentina, Ecuador, Bolivia, Dominican Republic and Chile, and is higher than $60 \%$ in the other countries.

As an indicator of violence, homicides rates are highest in El Salvador (82.8 per 100,000 people), and 56.6 in Venezuela, 56.5 in Honduras, 47 in Jamaica, 29.5 in Brazil, 25.5 in Colombia, and 19.6 in Mexico. Regarding the percentage of injuries in the total causes of death, the highest violent causes of death are observed in Honduras (19.6\%), Venezuela (19.2\%), Guatemala (15.7\%), Bolivia (13.1\%), Ecuador (12.8\%), Nicaragua (12.7\%), Haiti (2.6\%), and Brazil (12.2\%).

In 2017, poverty affected $19.3 \%$ of the Honduran population, followed by Guatemala, and the Gini index is highest in Brazil, Paraguay, Honduras, Panama, Colombia, Guatemala and Costa Rica.

Cultural diversity is higher in Bolivia, Guatemala, Peru, Mexico, Panamá, Honduras and Ecuador, but indigenous populations are excluded from healthcare. The difference in accessing health services when comparing the access of indigenous people and non-indigenous is highest in Panamá, Colombia, El Salvador, Brazil, Nicaragua, Bolivia, Peru and Costa Rica.

These inequalities and exclusion are obstacles to equity, and the poor, indigenous and afrodescendent people (who are the main beneficiaries of these systems), should develop their capacity for empowerment through their participation in decision-making mechanisms.

\section{CONTRADICTIONS AND LIMITATIONS OF FRAGMENTED SYSTEMS}

Latin America has alternate periods of decreases and increases in growth and in rates of formal employment and contributions to social security systems. Efforts have been made to increase coverage, accompanied by the reproduction of fragmentation in the generosity and quality of the benefits delivered by public and private pensions and health plans to the poorest and richest groups. Fragmentation is originated mainly in this separation of formal workers from those unemployed, informal, or their dependents. The first group contributes to their welfare on an individual basis, and the second wider group depends almost exclusively on the tax collection of the State. 


\section{Why contributory systems are unable to guarantee universal rights and social citizenship.}

Frequent flows between formal and informal employment throughout life suggest that most of the workers would not be able to retire, and nonetheless, the State will have to cover their pensions through non-contributory schemes, financed by taxes. In fragmented labor markets, the Seguro Popular in Mexico and the Regimen Subsidiado in Colombia promoted that around $5 \%$ of the formal workers moved to informal jobs; and older adults in Brazil and Mexico, upon receiving a non-contributory pension, stop working [20, 23, 30].

Reforms of the 1980s-1990s privatized contributive systems with negative results: 1 . Before privatization, the State was a third contributor and, as the manager, covered the administrative costs, 2. The State had to pay a high percentage of the GDP for privatization reforms, 3. To cover the risks of the privatized model, the State had to assume a commitment to pay the pensions in the cases of bankruptcies, crisis, and unemployment; in which contributors would not be able to achieve the right to retire, 3. Privatization replaced the defined benefits by defined contributions, and replaced collective public funds systems, based on intergenerational solidarity, on individual accounts in the private system.

Finally, the entire population and new workers are receiving lower pension values and have to work longer to compensate for current reductions [23]. In Chile, for example, in 2018, 50\% of workers who contributed for 30-35 years retired with $82 \%$ of the minimum wage -US\$188, and other $50 \%$ of new retirees, received pensions under US\$ 76 . The promised replacement rates of up to $70 \%$ were reduced to $13.78 \%$. Bankruptcies led to loss $30 \%$ of savings. The only certainty of the private system is that, nevertheless, the State will pay a minimum pension. In 1998, the State created the Pilar Solidario to pay a pension of $60 \%$ to the poorest and to subsidize the pensions provided by the private AFPs under $36 \%$ of the minimum wage - US \$ 1.27 .

After the privatization, the logic and values orienting welfare and social rights in Latin America are contradictory. In contributory systems, the main value of more privileged workers is the economic profitability of investments made individually in pension systems and in the taking advantage of using healthcare private plans. Regarding non-contributory policies, the general value is to support the most vulnerable groups with the scarce taxes collected by the States in Latin America.

\section{Inequalities - a persistent problem reinforced by rules in Latin America.}

According to the liberal perspective, the Bismarckian model, interconnected with the labor market, providing rights only to formal workers and penalizing formal companies, while subsidizing non-contributory policies, encouraging informality and tax evasion, and to dismiss salaried workers [38].

After privatization, everyone has lost in terms of generosity and quality of social benefits, even the middle class, who lost guarantees to have pensions until their deaths, and have to pay more to participate in private plans, which offer more restrictions and conditions in order to access highly specialized procedures.

Inclusion in social security depends not only on decisions of the State, but also on the flexibility of the retirement rules, on the confidence of the workers in the system and on the organizational power and stability of the affiliated workers, employers, and informal workers to claim their social rights [18]. For example: in Mexico, even with the old public fund, not even 
the majority of the $40 \%$ of contributors are able to retire - only $20 \%$ are retired and less than $5 \%$ of their widows have pensions.

Even workers with large labor trajectories could be unable to prove their contributions in the periods they were working, since most Latin American countries don't have a register of labor contracts - the companies deposit salaries and contributions in different institutions or banks, and searching for lifelong accounts and statements along life in multiple institutions has a high administrative cost.

Bureaucracy and complex regulations make difficult to prove contributions and to get in the old public bureaucracy and under the new private rules. At the end of the working life, even formal workers are asking for non-contributory support. In Mexico, for example, around 40\% of workers contribute to social security - however, only $20 \%$ of the elderly and less than $5 \%$ of widows have pensions, as a result, $80 \%$ of non-pensioned elderly have to work until their late life or receive support from their families [39].

\section{Challenges and opportunities to building Universalism in Latin America.}

The limited capacity of the State to collect taxes and insufficient public budgets is an argument used against social policies, in times of very high rates of growth or in crisis, nevertheless the liberal orientation continues to be to cut social budgets, and emergency measures are taken just to mitigate poverty, inequalities and social conflicts.

Fragmented institutional systems involve several actors and disputes and conflicts occur regarding the distribution of resources, management and reforms, and access to information, participation and decision-making.

[2] argues that today's citizens' rights are predominantly based on individual savings banks accounts accrued during working time, to support their own retirement or unemployed, without compromising redistribution between the richest and poorest citizens.

The main limitation of fragmented schemes is the conflict between more and less protected groups. The level and quality of benefits in each scheme vary enormously, and values and quality of benefits are insufficient to guarantee to the majority of population their rights and citizenship, reproducing the historical inequalities, social injustice, and discrimination.

Political disputes among interest groups and between them and the State have increased the costs of health and pensions, using the argument of demographic and epidemiological transitions. However, Latin America is already experiencing a demographic bonus of youth and adults of working age, and the elderly correspond to just to around $10 \%$ of the population.

The recognition of equal citizenship and rights is the main problem in elitist societies' formation and in the development of fragmented labor market and social policies. Security coverage for formal workers and social assistance coverage for the poor-informal (and in most countries this dual pattern remains to this day) generate conflicts. Paying taxes and support the poor have been motive for conflicts and protests in Latin American, particularly in the current context of high intolerance, polarization, and discrimination against indigenous, Afrodescendants and new immigrants from Latin America and Africa. In these unequal, fragmented and discriminatory societies, equality isn't highly valued. It is even considered undesirable for elites and middle classes. Inequalities and discrimination of the majority of the population reproduce the selective citizenship and the low quality of democracy that characterizes the region. 
Under the universalism perspective, the State should guarantee good health for all its citizens, and all sectors of society must be involved, which requires political, social and economic agreements, citizens' empowerment, and participation. These values depend not only on the economy, but also on the field of politics and the power of voting, dialogue, and negotiations between different social groups and democracy, which must be above the principles of economic globalization.

Under the universalism perspective, the State should guarantee good health for all the citizens, from which all sectors of society must be involved, which requires political, social and economic agreements, citizens' empowerment and participation.

\section{CONCLUSION}

Universalism or even universal coverage has never been achieved in Latin America, precisely due to the State and societies having never seriously debated the values of solidarity and equality as an axis of universal rights and citizenship. Few debates just lead to the incapability of the States in developing countries to provide universal protection. This socially and politically accepted limitation explains why expenses in health and pensions are lower in Latin America, compared to Europe, as well as benefits and rights effectively exercised.

On the contrary, universalism as a value is not sufficiently discussed and adopted, as social justice focused on equal opportunities, universal rights and citizenship. These values are submitted to the economic discussion, as rights and citizenship would depend only on the economy and on the position that each person assumes in society, on how they are legitimized in the field of politics, and the power of voting, dialogue and negotiations between different social groups in democracy. Universal principles must be above the economic goals and interests.

As a result, Latin America continues to reproduce the most heterogeneous and unequal societies in the world, such as in the economic, social classes, and the most diverse presence of ethnic-racial groups, co-existing under a traditional structure of the State and institutions controlled by elites, which are the main obstacle to developing Universalism.

That is why the humble improvements in social inclusion, limited in fragmented welfare and citizenship, are celebrated by progressive politicians, and harshly combated by elitist families and interest groups who have historically controlled the economy, the State, institutions and power with international partners.

\section{References}

Dwyer P. (2010). Understanding Social Citizenship (second Edition): Themes and Perspectives for policy and practice. Bristol, UK; Chicago, IL, USA: Bristol. University Press. DOI: 10.2307/j.ctt1t89hcn

Dean, H. (2002). Welfare rights and social policy. Pearson Education/Prentice Hall, Harlow, UK.

World Bank (2015). Indigenous Latin America in the twenty-first century: the first decade. Washington D.C.

UNDP. (2010). Informe Regional sobre Desarrollo Humano para America Latina. New York.

Freire, G.; Diaz-Bonilla, C., Schwartz Orellana, S. Soler Lopez, J. \& Carbonari, F. (2018). Afro-descendants in Latin America: Toward a Framework of Inclusion. World Bank, Washington, DC

Rubinstein, A., Zerbino, M.C., Cejas, C. \& López, A. (2018) Making Universal Health Care Effective in Argentina: A Blueprint for Reform, Health Systems \& Reform, 4:3, 203-213, DOI: 10.1080/23288604.2018.1477537

Hammann, M. \& Tauilp, L. (2001) Manual de Doenças mais Importantes, por Razões Étnicas, na População Brasileira Afro-descendente. Ministerio da Saúde. Brasília. 
Bowen, G. (2009). Document Analysis as a Qualitative Research Method. Qualitative Research Journal, vol. 9, no. 2, $27-40$

Ridley, D. (2008) Methodology of the Literature Review. In Lisa M. Given (Ed.) The SAGE Encyclopedia of Qualitative Research Methods. DOI: https://dx.doi.org/10.4135/9781412963909.n249

Burgos R.N.B (2008). Universalismo y particularismo en la globalización. Propuesta Educativa, 15(30) 9-22.

Stanley, J \& Stein, B. (1970). The colonial heritage of Latin America: essays on economic dependence in perspective, Estudios Internacionales 4(14) 150-153. New York: Oxford University Press. DOI: 10.5354/07193769.2012 .18890

Prebish, R. (1963). Hacia una dinámica del desarrollo latinoamericano. México. Fondo de Cultura Económica. Mexico.

Furtado, C. (1975) El desarrollo económico, un mito. Siglo XXI. Mexico.

Buarque de Holanda, S. (1978). Raízes do Brazil. 12. ed. Rio de Janeiro: José Olympio.

Ocampo, J.A. (2012). La historia y los retos del desarrollo latinoamericano. CEPAL. Chile https://repositorio.cepal.org/bitstream/handle/11362/3090/1/S2012833_es.pdf

Baum, S. (1992). Poverty, Inequality, and the Role of Government: What Would Adam Smith Say? Eastern Economic Journal, 18(2), 143-156. https://www.jstor.org/stable/40325376

Temporao J.G. (2012). Universal Health Systems in a World in Transformation. Sistemas Universales de Salud en el Mundo en Transformación. ISAGS (2012) Health Systems in Southamerica, challenges to universalism, integrality and equitly. (pp. 13-20). Instituto Suramericano de Gobierno en Salud. ISAGS- Unasur. Rio de Janeiro.

Sánchez-Alonso, B. (2019). The age of mass migration in Latin America. The Economic History Review. 72(1) 3-31. https://doi.org/10.1111/ehr.12787

Oliveira, J. \& Teixeira, S. (1985). (IM)-Previdencia Social, 60 anos da historia da Previdencia no Brazil. Ed. Vozes. Petrópolis.

Mesa-Lago, C. (2007). Social Security Principles, Enforcement in Latinamerica, and Modifications by the reforms. Oxford University Press.

Giovanella L., Ruiz G., Feo O., Tobar S. \& Faria M. (2012). Sistemas de Salud en América del Sur, In Sistemas Universales de Salud en el Mundo en Transformación, desafíos para la universalidad, integralidad y equidad. (pp. 2170). Instituto Suramericano de Gobierno en Salud. ISAGS- Unasur. Rio de Janeiro.

Stormansan, J. (2011). Los años del capitalism renovado: la influencia de Milton Friedman en Chile. La instauración del modelo económico. Espacio Regional 2(8) 57-76. Osorno, Chile.

Levy, S. \& Schady, N. (2013). Latin America's Social Policy Challenge: Education, Social Insurance, Redistribution. The Journal of Economic Perspectives, 27 (2) Spring. 193-218. DOI: 10.1257/jep.27.2.193

Mesa-Lago C. (1992). Health Care for the Poor in Latin America and the Caribbean. Inter-American Foundation and Pan American Health Organization, PAHO Scientific Publication, No. 539. Washington, DC. http://apps.who.int/bookorders/anglais/detart1.jsp?codlan=1\&codcol=61\&codcch=539

Cruz-Saco, M. \& Mesa-Lago, C. (1998). The Reform of Pension and Health Care Systems in Latin America. Do Options Exist? University of Pittsburgh Press.

Diamond, P. (1993). Privatization of Social Security: Lessons From Chile. Working Paper n.4510. National Bureau of Economic Research. Cambridge MA. https://www.nber.org/papers/w4510

De Ferranti, D., Perry, G., Ferreira, F., Walton, M., Coady, D., Cunningham, W. \& Wodon, Q. (2003). Inequality in Latin America and the Caribbean: Breaking with History? Washington: World Bank.

Stiglitz, Joseph. (2010). Los felices 90. La semilla de la destrucción, Madrid: Santillana Ediciones Generales.

Ortiz, I., Durán-Valverde, I., Urban, S., Wodsak, V. \& Yu, Z. (2019). Reconstruyendo los sistemas públicos de pensiones en los países de Europa Oriental y América Latina (2000-2018) ESS - Documento de trabajo núm. 63 (pp. 1-24) Departamento de Protección Social OIT/ILO Switzerland.

Arza, C. (2008). Pension Reform in Latin America: Distributional Principles, Inequalities and Alternative Policy Options. Journal of Latin American Studies, 40(1), 1-28. DOI: https://doi.org/10.1017/S0022216X07003616

Avelino, G; Brown, D.S \& Hunter, W. (2005), The Effects of Capital Mobility, Trade Openness, and Democracy on Social Spending in Latin America, 1980-1990. American Journal of Political Science, 49(3), 625-641. DOI:

10.2307/3647736. http://www.propuestaeducativa.flacso.org.ar/archivos/dossier_articulos/21.pdf 
Fleury, A.S. (2001). Universal, Plural or Dual? Models and Challenges in Health Attention in Latin America. In C.G. Molina \& J. N. del Arco (Eds.) Health Services in Latin America and Asia Modelos y Dilemas de la Atención de la Salud en América Latina. Interamerican Development Bank. - INDES. (pp. 3-36). Washington D.C.

Londoño J.L \& Frenk, J. (1997). Structural pluralism: towards an innovative model for health system reform in Latin America. Health Policy 1997; 1-36. https://www.ncbi.nlm.nih.gov/pubmed/10169060

WHO (2009) Health Workforce, Infrastructure, Health Medicines, World Health Statistics.

Laurell C. (2011). Acceso Universal: Sistemas Únicos vs Aseguramiento. In: Sistematizando Lecciones y Experiencias en la Construcción de Sistemas Únicos de Salud, Ministerio de Salud de Bolivia: La Paz.

https://www.paho.org/ecu/index.php?option=com_docman\&view=download\&category_slug=documentosnoticias-2012\&alias=403-sistemas-universales-de-salud-retos-y-desafios\&Itemid=599

Rubinstein, A., Barani, M. \& Lopez, A. (2018). Quality first for effective universal health coverage in low-income and middle-income countries. The Lancet Global Health 6(11) 1142-1143. DOI:https://doi.org/10.1016/S2214109X(18)30447-9

Kruk, M.E., Gage A.D., Arsenault C., Jordan, K., Leslie H.H, Roder-DeWan, S., Adeyi, O., et al. (2018). High-quality health systems in the Sustainable Development Goals era: time for a revolution. The Lancet Global Health. 6: 11961252. DOI:https://doi.org/10.1016/S2214-109X(18)30386-3

Pagés, C. (2010). La era de la productividad: cómo transformar las economías desde sus cimientos. Serie Desarrollo en las Américas (DIA). Washington, D.C.: BID. https://publications.iadb.org/es/publicacion/la-era-de-laproductividad-como-transformar-las-economias-desde-sus-cimientos

Gomes, C. (1995). Envejecimiento Poblacional en México: la crisis vecina. Master Thesis. FLACSO Mexico. 